\title{
Fire Management in the National Wildifie Refuge System: A Case Study of the Charles M. Russell National Wildife Refuge, Montana
}

\section{By Angela M. Reid and Samuel D. Fuhlendorf}

\section{Introduction}

1 ire research has been on the rise in the last 20 years, and there is increasing interest in determining fire's role in virtually every ecosystem throughout the United States and much of the world. Much of the recent research has identified the importance of fire to rangeland ecosystems and suggests that understanding historical fire regimes and the natural range of variation is critical to adaptive ecosystem management of all rangelands. The US Fish and Wildlife Service (USFWS) is entrusted with around 60 million ha on 552 National Wildlife Refuges in all 50 states and US territories, and maintaining and restoring historical fire regimes are important issues on over 30 million ha. ${ }^{1}$ The USFWS National Wildlife Refuge System is critical to conservation in the United States and is a dominant player in fire management.

Currently the USFWS manages more prescribed burns than wildfires each year and burns a higher percentage of their land holdings than other federal agencies with an annual average of more than 121,000 ha $(0.4 \%$ of their total burnable area). ${ }^{2}$ National Wildlife Refuge land is also used for many past and ongoing fire research projects. ${ }^{3,4}$ Active fire management is a stated goal of the USFWS, and the majority of refuges are dependent on fire to restore and maintain ecosystem structure and function. ${ }^{1}$ Our objective for this paper is to examine temporal and spatial fire distributions and evaluate the fire management on one of the USFWS's largest refuges, the Charles M. Russell (CMR) National Wildlife Refuge in Montana. We compare the current fire regime of the CMR (1980-2008) to historical fire regime reconstructions using $\mathrm{LANDFIRE}^{5}$ and discuss the potential implications and challenges to land management that are related to fire on the CMR.

\section{The Charles M. Russell National Wildlife Refuge}

The Charles M. Russell National Wildlife Refuge covers approximately 430,000 ha, of which about 331,000 ha is land area, and is located in northeastern Montana about $105 \mathrm{~km}$ northeast of Lewistown, Montana. The refuge follows the Missouri River approximately $201 \mathrm{~km}$ west from the Fort Peck Dam and contains a diverse array of vegetative communities, including native prairies, forested coulees, river bottoms, and badlands (Fig. 1). Upland sites on the refuge are dominated by mixed-prairie grasses and native shrubs including Wyoming big sagebrush (Artemisia tridentata Nutt. ssp. wyomingensis Beetle \& Young), plains pricklypear (Opuntia polyacantha Haw.), winterfat (Krascheninnikovia lanata [Pursh] A. Meeuse \& Smit), rubber rabbitbrush (Ericameria nauseosa [Pall. ex Pursh] G. L. Nesom \& Baird ssp. nauseosa var. nauseosa), and Gardner's saltbush (Atriplex gardneri [Moq.] D. Dietr.). Species present on the vegetated slopes leading down to the Missouri River include common chokecherry (Prunus virginiana L.), golden currant (Ribes aureum Pursh), quaking aspen (Populus tremuloides Michx.), and Rocky Mountain juniper (Juniperus scopulorum Sarg.). Ecological Site Descriptions, listing historical climax plant community species composition, for sites on the refuge indicate that the most dominant shrubs on the refuge (Wyoming big sagebrush, plains pricklypear, Rocky Mountain juniper) were historically a much smaller portion of these communities' species composition while the other listed shrubs have declined across the landscape. ${ }^{6}$ Additionally, refuge records of historical narrative corroborate the decline of the aforementioned species on refuge lands. The shrubs that are currently dominant on the refuge are characterized 

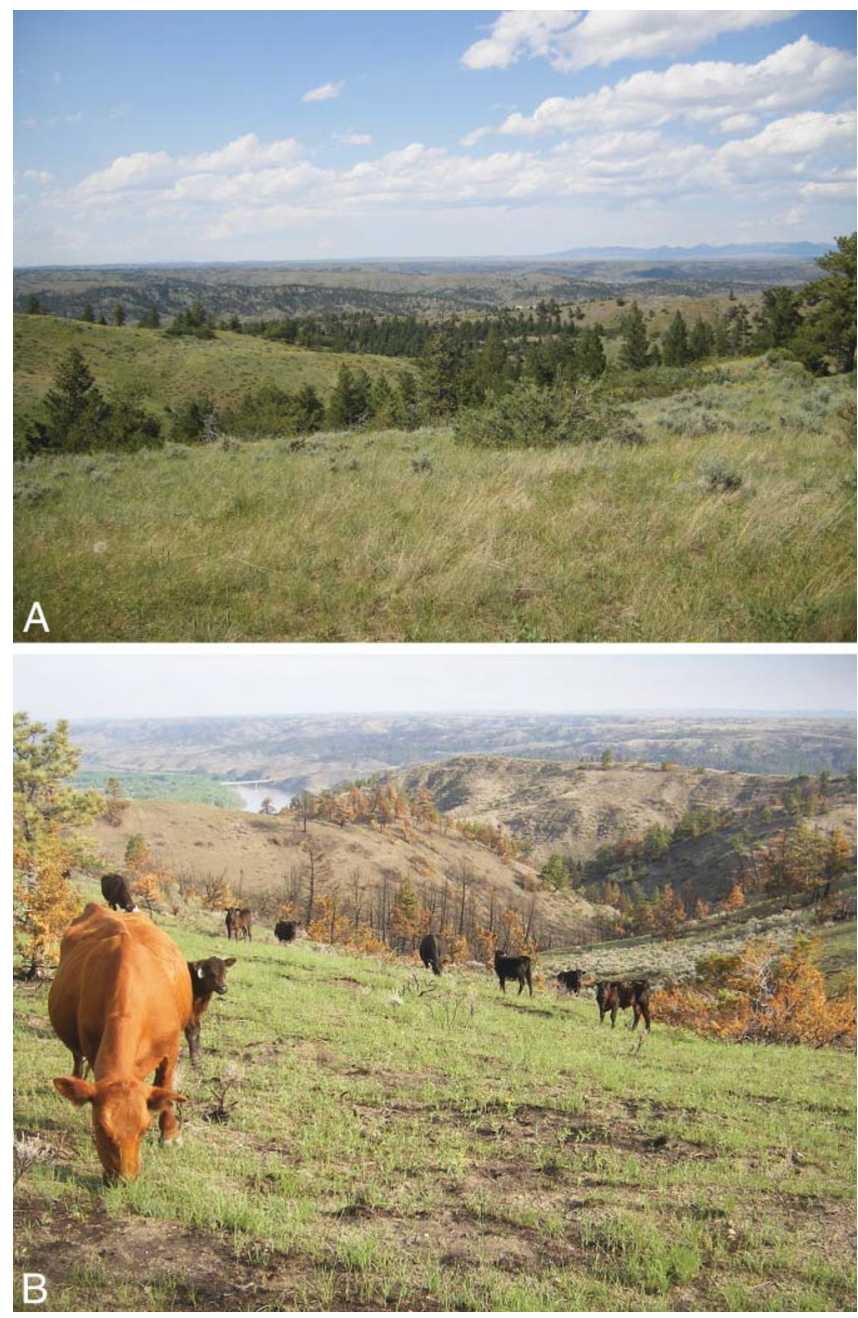

Figure 1. The Charles M. Russell National Wildlife Refuge, Montana, is a very diverse landscape. A, Wyoming sagebrush-dominated upland in the foreground and forested slopes leading to the Missouri River bottomlands. B, Cattle grazing on the slopes of a 2008 prescribed fire.

by low fire tolerance and no resprout ability, while most of those that have declined are fire-tolerant species. ${ }^{7}$

The CMR provided a copy of the historical fire records in Geographic Information System (GIS) format, which included data from 1980-2008. Refuge records are continuously being revised as more information is gathered about past fires; therefore this does not represent a conclusive fire history for the time period evaluated. However, this is the most updated data set based on the information the refuge staff currently has. All records of fires that occurred entirely or partially on the refuge and contained full spatial and temporal data were used. For those fires that burned across CMR borders, only the area burned within the refuge was used in calculations. Ignition source and spatial and temporal distribution of fires were examined. Maps were produced using ArcMap Version 9.2.

\section{Current Fire Regime (1980-2008)}

On the CMR, an increasing trend of area burned is clear for the period 1980-2008. Over the last three decades 21.6\% of the CMR burned, over half of that occurred in the last four years (even when data without spatial references are considered, the figure is only $26.7 \%$ using the estimated fire area provided in CMR records; see Table 1). The period 2000-2004 had the second highest area burned, yet it was only one-fourth as much as in 2004-2008. Overall, the number of fires declined slightly over time but the amount of area burned increased. Evidence of this can be seen in the increase of maximum fire size recorded during the observation period. The smallest maximum fire size recorded on the refuge for a single five-year period was 1,214.0 ha and occurred in 1985-1989. The largest maximum fire size recorded was 26,918.5 ha and occurred in 2000-2004. Minimum fire sizes are relatively constant throughout the entire time period and are never larger than 1 ha, likely due to the effectiveness of the CMR fire crew as well as sparse fuels across parts of the refuge. Also, ignition by campfires and cooking units account for some records and were likely extinguished quickly.

The majority of all fire ignitions were caused by lightning (Table 1). Lightning accounted for 63.3-93.9\% of ignitions for each five-year period. Human-caused ignitions, commonly campfire escapes, were the second most common, and prescribed fire ignitions accounted for the least number among known ignition sources and varied 0-13.2\%. Most prescribed fire ignitions were recorded during the 2004-2008 period. In 2008 CMR conducted 580.7 ha of prescribed burns out of a total 15,655.6 ha conducted across the entire USFWS Mountain-Prairie Region, which amounts to only $3.7 \%$ of all prescribed burns in the region. ${ }^{1}$ Refuge records indicate that area burned on the refuge, fire size, as well as the use of prescribed fire increased over the period examined.

The spatial pattern of fires on the landscape also follows a trend. In general, for every five-year period, fires are largest and more numerous in the central portion of the refuge (Fig. 2). One possible explanation for this is the location of an "ignition hotspot" created by increased lightning occurrence due to surrounding mountain ranges. ${ }^{9}$ The Little Rocky, Snowy, Judith, and Bears Paw mountain ranges surround the western portion of the refuge and influence the weather by producing lightning strikes often associated with little or no rainfall, also known as a rain shadow effect. Increased lightning occurrence, in combination with other factors including topography, soils, and fine fuels, creates this concentration of fires. Regardless of the cause, this portion of the refuge has had a strong tendency to burn over the last several decades.

The fire rotation for the CMR is approximately 134 years, meaning it would take that many years for an area the size of the refuge to burn. The fire rotation was calculated using the following equation:

$$
\text { Fire Rotation }=\frac{\text { No. of Years }}{\left(\frac{\text { Area Burned }}{\text { Total Area }}\right)}
$$




\begin{tabular}{|c|c|c|c|c|c|c|c|c|c|}
\hline \multirow[b]{2}{*}{ Years } & \multirow{2}{*}{$\begin{array}{c}\text { Area } \\
\text { burned } \\
\text { (ha) }\end{array}$} & \multirow{2}{*}{$\begin{array}{l}\% \text { total } \\
\text { refuge } \\
\text { area* }\end{array}$} & \multirow[b]{2}{*}{ No. fires } & \multirow[b]{2}{*}{$\begin{array}{l}\text { Min. fire } \\
\text { size (ha) }\end{array}$} & \multirow[b]{2}{*}{$\begin{array}{l}\text { Max. fire } \\
\text { size (ha) }\end{array}$} & \multicolumn{4}{|c|}{ Ignition source ( $\%$ total) } \\
\hline & & & & & & Lightning & $\begin{array}{l}\text { Human- } \\
\text { caused }\end{array}$ & $\begin{array}{c}\text { Prescribed } \\
\text { fire }\end{array}$ & Othert \\
\hline $1980-1984$ & $4,163.0$ & 1.3 & 49 & 3.81E-03 & $4,007.1$ & 93.9 & 4.1 & 0.0 & 2.0 \\
\hline $1985-1989$ & $2,829.5$ & 0.9 & 75 & $1.64 \mathrm{E}-05$ & $1,214.0$ & 92.0 & 4.0 & 1.3 & 2.7 \\
\hline $1990-1994$ & $5,823.0$ & 1.8 & 49 & 0.07 & $4,478.7$ & 63.3 & 30.6 & 4.1 & 2.0 \\
\hline 1995-1999 & $7,751.1$ & 2.3 & 29 & 5.71E-04 & $4,061.5$ & 93.1 & 3.5 & 0.0 & 3.5 \\
\hline $2000-2004$ & $10,509.9$ & 3.2 & 36 & 0.04 & $26,918.5$ & 83.3 & 13.9 & 0.0 & 2.8 \\
\hline $2005-2008$ & $40,579.9$ & 12.3 & 38 & 0.03 & $13,345.2$ & 79.0 & 5.3 & 13.2 & 2.6 \\
\hline $1980-2008$ & $71,656.4$ & 21.6 & 276 & 1.64E-05 & $26,918.5$ & 84.4 & 10.1 & 2.9 & 2.5 \\
\hline
\end{tabular}

Area burned was calculated for refuge lands only, and the percent of total refuge area was calculated using the land area of the refuge (331,000 ha). Minimum and maximum fire sizes take into account total area burned, on and off refuge, and give a better idea of the range of fire sizes.

* Total area was calculated by subtracting the area of the Missouri River and Fort Peck Reservoir from the total area.

tOther ignition sources included things such as unknown sources and power lines.

A number of fires on the refuge burned in the same area, meaning that it would actually take longer for every portion of the refuge to burn. From a natural range of variation approach, it is challenging to determine if this relatively short record is an indication of the need for more fire on the landscape from an evolutionary perspective. The National Wilderness Coordinator, Nancy Roeper, pointed out that "fire plays a leading role on refuges with large wilderness tracts" and refers to the CMR as one such example..$^{10}$ Understanding historical fire regimes may be critical in
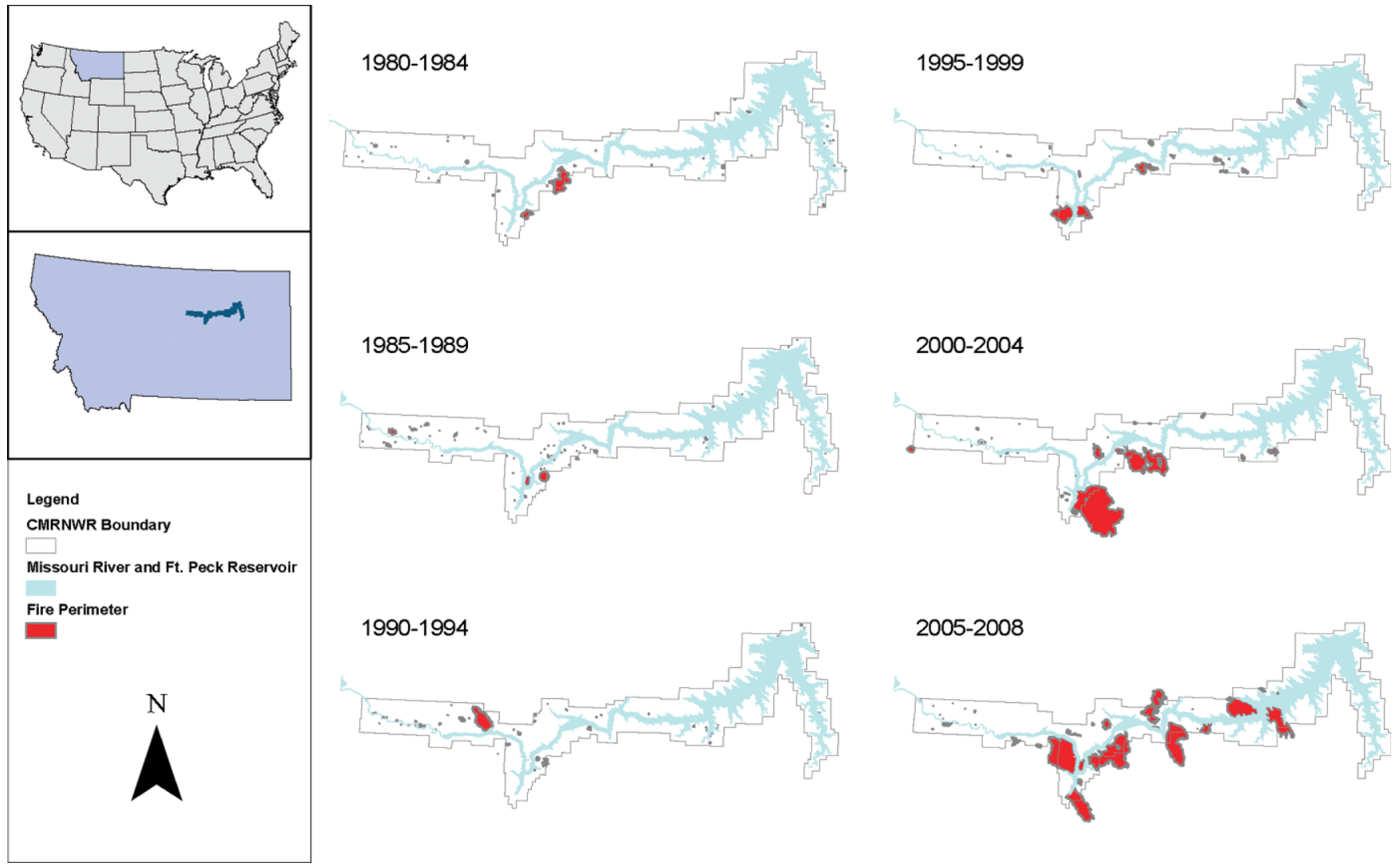

1990-1994

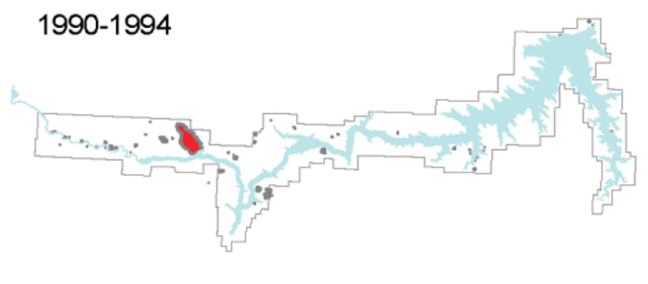

2005-2008

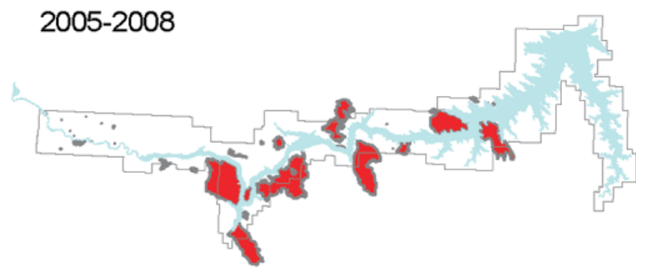

Figure 2. Fire occurrences recorded on the Charles M. Russell National Wildlife Refuge, Montana, for 1980-2008 separated into five-year groupings. Number and size of fires appear to increase with time and are generally located in the central portion of the refuge. 
defining the range of variation and developing an adaptive plan that is capable of sustaining ecosystem structure and function of this complex landscape.

\section{Historic Fire Regime}

LANDFIRE, the Landscape Fire and Resource Management Planning Tools Project, is a national comprehensive landscape-level planning tool for fire and resource management that provides maps and data describing vegetation, wildland fuels, and fire regimes using reference conditions of pre-Euro-American settlement. ${ }^{5}$ The project was a joint effort between the US Department of Agriculture Forest Service and Department of the Interior, which houses the USFWS. LANDFIRE products are created using extensive field-referenced data and provide 30-m-grid spatial resolution. One of the project's principle purposes is to provide national landscape-level geospatial data for the purpose of fire and fuels management planning. Though it may not be possible to know exactly what the landscape looked like in pre-settlement times, LANDFIRE goes a long way toward providing estimated reference conditions.

We utilized GIS layers for the Fire Regime Condition Class (FRCC), Fire Regime Group (FRG), and Mean Fire Return Interval (MFRI) to evaluate the current status of fire on the refuge (Fig. 3). ${ }^{11,12}$ The FRCC provides information on the departure of current vegetation from presumed historical conditions; there are three classes: low, medium, and high (Table 2). Class I, low departure, is considered to be within the natural range of variation and is generally considered ideal. Classes II and III describe increasing departure from historic conditions and are the dominant classes represented on the CMR (Fig. 3A). Very few small areas on the refuge are considered to be within the bounds of the natural range of variation for the historic fire regime. These areas are largely considered to be local fire refugia, meaning they historically burned on very long intervals, and the recent lack of fire is not unusual for these sites. The historic FRG varies across the landscape but Group II, 0-to-35-year frequency with replacement severity, and Group IV, 35-to-200-year frequency with replacement severity, are dominant throughout the refuge (Fig. 3B; Table 2). Though there is a wide range of fire frequencies, the entire refuge is dominated by a high-severity fire regime. Modern wildfires that break out on the refuge burn with stand replacing severity burning the canopies of shrubs and trees; however, prescribed fires are planned to burn with low severity.

Figure $3 \mathrm{C}$ provides a more detailed look at the range of historic MFRIs, the number of years between successive fire events, for the refuge. Fire return intervals are the longest near waterways throughout the refuge, including the Missouri River and associated coulees, and in portions near the eastern refuge boundary characterized by badlands and poor fuel continuity. The remainder of the refuge is dominated by a historic MFRI ranging from 21 to 45 years as determined by the number of pixels present in each interval across the refuge (Fig. 4). The least common MFRI is 11-15 years followed by $1,000+$ years, and the most common on the refuge is $26-30$ years. We calculated the average MFRI for the entire refuge to be 48.0 years based on the weighted average of all pixels assigned a MFRI value. According to LANDFIRE's historic reconstructions much more than $21.6 \%$ of the refuge would have burned in the last 29 years, and much of it would have burned with stand replacing severity in the absence of active fire suppression. So why didn't it?

\section{The Sagebrush Dilemma}

Many additional factors come into the decision-making process of ecosystem management regarding fire, including existing conditions, desired future conditions, and social and economic concerns. ${ }^{13}$ USFWS fire policy dictates how fire management is used on refuges and includes "assessing the purpose for which the refuge was established, applicable laws and ordinances, policies and regulations, local conditions, and social concerns," which includes complying with the Endangered Species Act. ${ }^{1}$ The refuge was partially established for sharp-tailed grouse management and currently has populations of one endangered species, the black-footed ferret, and one species of management concern, the sage grouse. Both grouse species, sharp-tailed and sage, utilize sagebrush steppe habitat, and sage grouse are considered to be sagebrush obligates. ${ }^{14-16}$ Black-footed ferrets require prairie dog towns, which are nestled among the big sagebrush-dominated uplands on the refuge. Due to the dependence of such species on this community, management of Wyoming big sagebrush communities has become a highly debated topic in the western United States.

Opposing recommendations about the use of fire in big sagebrush communities and debate about the historic MFRI are present throughout scientific literature, creating confusion among land managers. Figures range 50-240 years for the MFRI of big sagebrush, with Wyoming big sagebrush having the longest MFRI among the subspecies, and many researchers caution against the use of fire as a management tool. ${ }^{17,18}$ For researchers concerned with the fate of sage grouse prescribed fire is particularly unwelcome. Researchers are in agreement that Wyoming big sagebrush is killed by fire and use this as a justification to condemn the use of fire to maintain the recommended levels of needed habitat for sagebrush obligate and other species. Yet one study found that recommended vegetation cover values for different types of sage grouse habitat exceed the potential of a significant portion of the Wyoming big sagebrush alliance at or above the stand level, ${ }^{19}$ meaning that any land manager trying to impose these values on the landscape is attempting to create densities much higher than what is natural. Additionally, fires characteristic of Wyoming big sagebrush communities are rarely complete and often have large areas inside the fire perimeter that are unburned due to lack of a continuous fine fuel layer. As much as $90 \%$ within the fire 


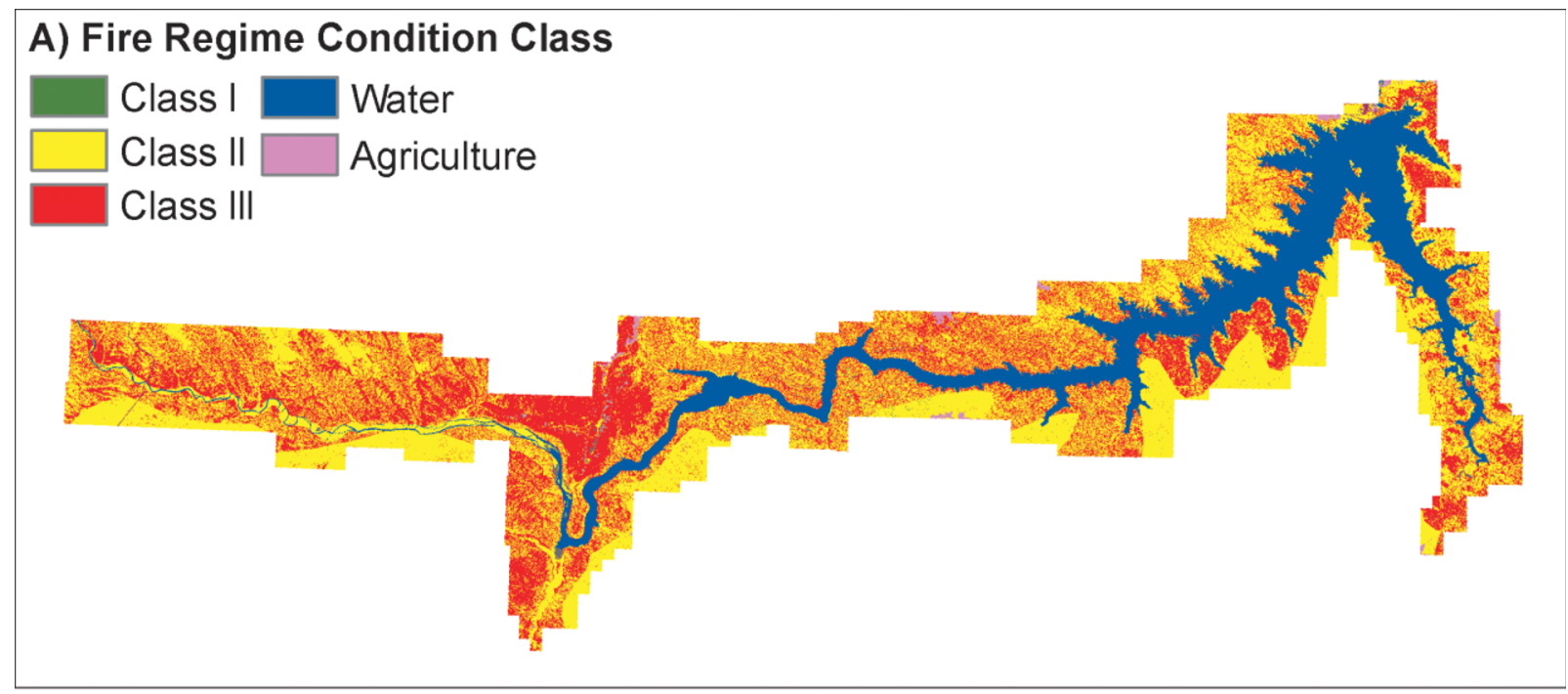

\section{B) Fire Regime Group}

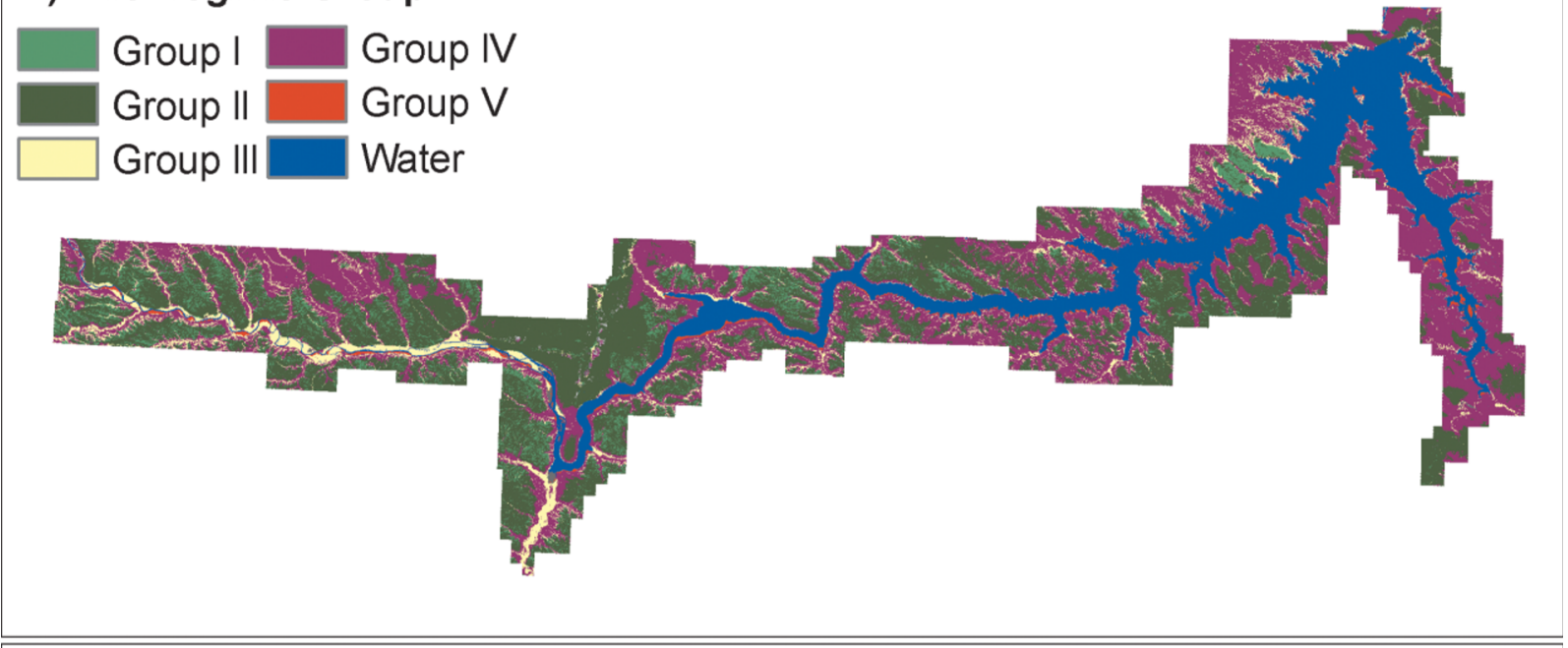

\section{C) Mean Fire Return Interval (years)

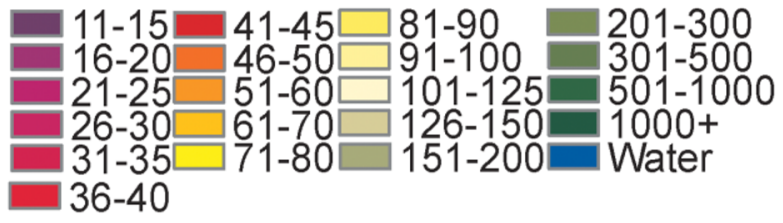

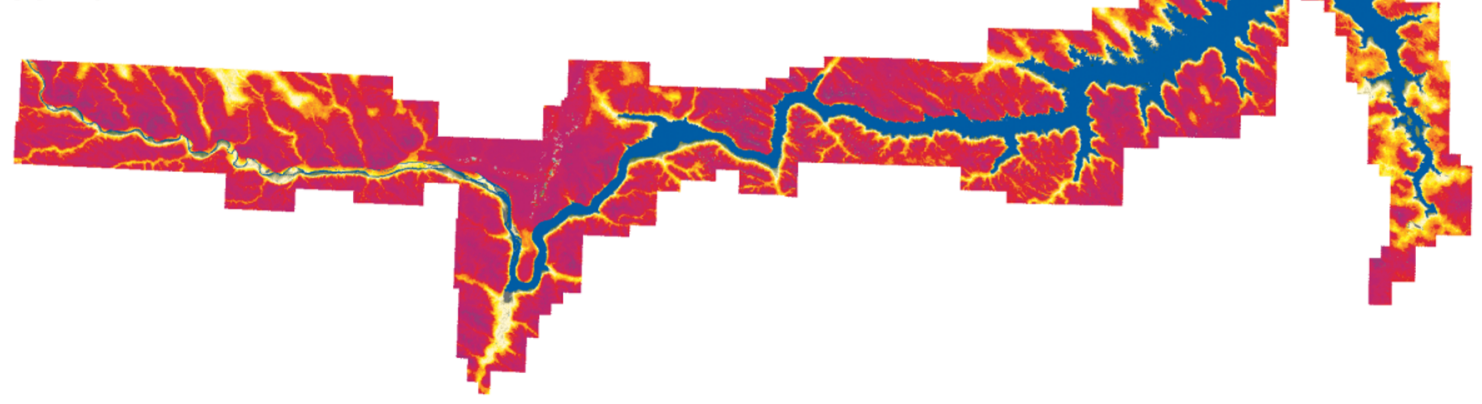

Figure 3. The Fire Regime Condition Class (FRCC), Fire Regime Group (FRG), and Mean Fire Return Interval (MFRI) for the Charles M. Russell National Wildlife Refuge, Montana, based on pre-Euro-American settlement conditions. A, Generally, this shows that the refuge has high to moderate departure from the historic fire regime (Table 2). B, The western half is characterized mostly by a historic fire regime of 0-to-35-year frequency and replacement severity (Group II), and the eastern half is a mixture between Group II and Group IV, 35-to-200-year frequency and replacement severity (Table 2). C, The historic MFRI for the refuge varies but mostly falls between 21 and 45 years. 


\begin{tabular}{|c|c|c|}
\hline Class/group & $\begin{array}{l}\text { Fire regime } \\
\text { condition } \\
\text { class }\end{array}$ & Fire regime group \\
\hline I & $\begin{array}{l}\text { Low } \\
\text { departure }\end{array}$ & $\begin{array}{l}\text { 0-to-35-year frequency, } \\
\text { low to mixed severity }\end{array}$ \\
\hline \| & $\begin{array}{l}\text { Moderate } \\
\text { departure }\end{array}$ & $\begin{array}{l}\text { 0-to-35-year frequency, } \\
\text { replacement severity }\end{array}$ \\
\hline III & $\begin{array}{c}\text { High } \\
\text { departure }\end{array}$ & $\begin{array}{l}\text { 35-to-200-year frequency, } \\
\text { low to mixed severity }\end{array}$ \\
\hline IV & - & $\begin{array}{l}\text { 35-to-200-year frequency, } \\
\text { replacement severity }\end{array}$ \\
\hline V & - & $\begin{array}{c}200+-y e a r \text { frequency, } \\
\text { any severity }\end{array}$ \\
\hline
\end{tabular}

perimeter has been recorded to remain intact and untouched by flames for prescribed fires and up to $28 \%$ for wildfires (Table 1). ${ }^{18}$ Mosaic fires are characteristic of this dry region and create a landscape that continually provides necessary habitat requirements for many species on the landscape level.

Wyoming big sagebrush recovery rates (which are used to determine MFRI) are calculated by comparing post-burn measurements to pre-burn cover and height conditions, but the pre-burn conditions being measured may be a remnant of large-scale fire suppression in the region. In their 2003 study, Wrobleski and Kauffman alluded to increased sagebrush dominance due to overgrazing and fire suppression. ${ }^{20}$ The spread of cheatgrass (Bromus tectorum L.) is another justification used to bar fire from these ecosystems; however, cheatgrass is not currently a problem on the CMR. Additionally, fire used in areas largely composed of native perennials resulting in low mortality of these perennials has been shown not to induce an increase of cheatgrass. ${ }^{21}$ Many of the reasons not to use fire in big sagebrush ecosystems do not hold true on the CMR, and the results of our comparison between reconstructed historic conditions and current fire regime imply that the CMR should incorporate more fire into their planned land management. The high proportion of lightning ignitions and the large amounts of area burned by wildfire make it obvious that fire cannot be completely suppressed on the refuge, making it all the more important to incorporate the use of fire so that more control can be implemented and management goals obtained. It is important that management plans incorporate key sage grouse areas for special concern, but most of the refuge has significantly deviated from historic fire regimes and is not important to sage grouse.

\section{The Way Forward}

Managers and biologists struggle to make fire management decisions that benefit all species utilizing the natural resources

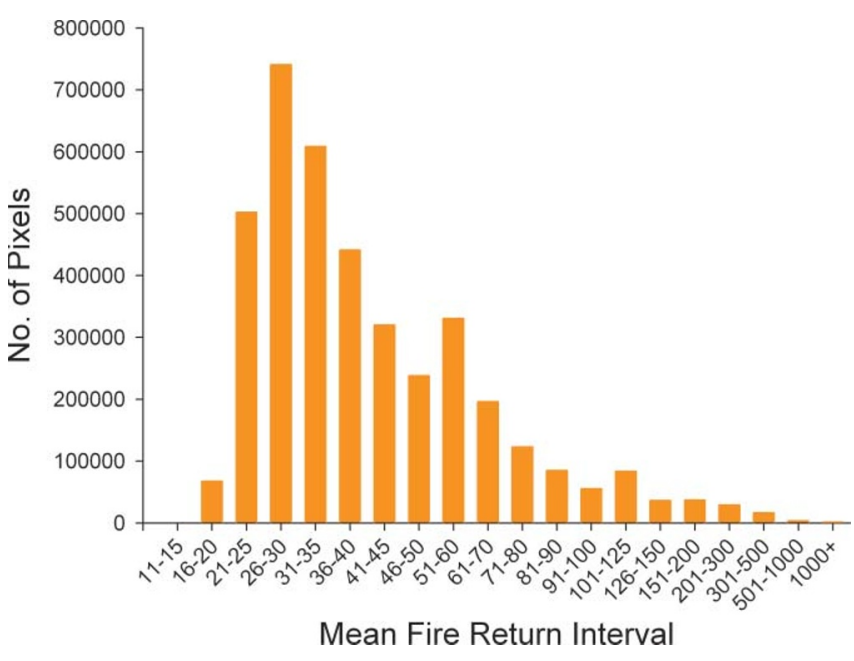

Figure 4. The historic Mean Fire Return Interval (MFRI) for the Charles M. Russell National Wildlife Refuge, Montana. A MFRI spatial layer ${ }^{11}$ was provided by LANDFIRE and used to determine the number of pixels within each interval on the refuge. The most common MFRI is 26-30 years, and the least common is $11-15$, followed by $1,000+-$ year intervals.

on the refuge. A few decades ago total fire suppression was occurring on most federal lands across the country, but that phase is ending as the benefits and necessity of fire on the landscape are realized. Similarly, fire should not be uniformly and haphazardly applied to complex landscapes. Sensitive and critical species must be considered, and fire should promote a mosaic that takes into account fire history as well as current management objectives. Natural resource managers are transitioning into a period when managing ecosystem drivers, such as fire, is just as important as individual species as we learn just how intertwined those management goals are. It is our hope that the trend of increasing fire, prescribed fire specifically, on the Charles M. Russell National Wildlife Refuge is a continuing one, and it becomes an important part of their management objectives.

\section{References}

1. USFWS. 2009. Fire management. Available at: http://www. fws.gov/fire. Accessed 2 November 2009.

2. Street, P. 2004. Keeping fire on our side. U.S. Fish and Wildlife Service National Wildlife Refuge System Refuge Update 1:10-11.

3. Madden, E. M., A. J. Hansen, and R. K. Murphy. 1999. Influence of prescribed fire history on habitat and abundance of passerine birds in northern mixed-grass prairie. Canadian Field-Naturalist 113:627-640.

4. Drobyshev, I., P. C. Goebel, D. M. Hix, R. G. Corace III, and M. E. Semko-Duncan. 2008. Interactions among forest composition, structure, fuel loadings and fire history: a case study of red pine-dominated forests of Seney National Wildlife Refuge, Upper Michigan. Forest Ecology and Management 256:1723-1733.

5. USDA, FS, AND USDOI. 2009. LANDFIRE. Available at: http://www.landfire.gov/index.php. Accessed 8 November 2009. 
6. USDA, NRCS-MT. 2009. Electronic field office technical guide. Fergus County, MT. Available at: http://efotg.nrcs.usda. gov/treemenuFS.aspx. Accessed 22 October 2009.

7. USDA, NRCS. 2009. The PLANTS database. Available at: http://plants.usda.gov. Accessed 21 October 2009.

8. ArcMap [software]. 2006. Version 9.2. Redlands, CA, USA: Environmental Systems Research Institute.

9. Frost, C. C. 2008. Natural fire regimes and pre-European settlement vegetation of the Charles M. Russell National Wildlife Refuge. In-House Research Report. Lewistown, MT, USA: US Fish and Wildlife Service, Charles M. Russell National Wildlife Refuge. 87 p.

10. Gleason, K. M. 2004. Wildfire in wilderness: good for wildlife. U.S. Fish and Wildife Service National Wildife Refuge System Refuge Update 1:14-15.

11. USDOI, GS. 2006. The National Map LANDFIRE: LANDFIRE National Fire Regime Groups layer and Mean Fire Return Interval layer. Available at: http://gisdata.usgs.net/ website/landfire. Accessed 5 November 2009.

12. USDOI, GS. 2007. The National Map LANDFIRE: LANDFIRE National Fire Regime Condition Class layer. Available at: http://gisdata.usgs.net/website/landfire. Accessed 5 November 2009.

13. Haufler, J. B., C. A. Mehl, and G. J. Roloff. 1996. Using a coarse-filter approach with species assessment for ecosystem management. Wildlife Society Bulletin 24:200-208.

14. Connelly, J. W., M. W. Gratson, and K. P. Reese. 1998. Sharp-tailed grouse (Tympanuchus phasianellus). Number 354. In: A. Poole and F. Gill [eds.]. Birds of North America. Philadelphia, PA, USA: The Birds of North America, Inc. 19 p.

15. Connelly, J. W., M. A. Schroeder, A. R. Sands, and C. E. Braun. 2000. Guidelines to manage sage grouse populations and their habitats. Wildlife Society Bulletin 28:967-985.
16. Schroeder, M. A., J. R. Young, and C. E. Braun. 1999. Sage grouse: Centrocerus urophasianus. Number 425. In: A. Poole and F. Gill [eds.]. Birds of North America. Philadelphia, PA, USA: The Birds of North America, Inc. 28 p.

17. Wright, H. A., And A. W. Bailey. 1982. Fire ecology: United States and southern Canada. New York, NY, USA: John Wiley \& Sons. $501 \mathrm{p}$.

18. Baker, W. L. 2006. Fire and restoration of sagebrush ecosystems. Wildlife Society Bulletin 34:177-185 (see particularly Table 1).

19. Davies, K. W., J. D. Bates, and R. F. Miller. 2006. Vegetation characteristics across part of the Wyoming big sagebrush alliance. Rangeland Ecology \& Management 59:567-575.

20. Wrobleski, D. W., and J. B. Kauffman. 2003. Initial effects of prescribed fire on morphology, abundance, and phenology of forbs in big sagebrush communities in southeastern Oregon. Restoration Ecology 11:82-90.

21. Bates, J. D., E. C. Rhodes, K. W. Davies, and R. Sharp. 2009. Postfire succession in big sagebrush steppe with livestock grazing. Rangeland Ecology E Management 62:98-110.

Authors are Fire Ecology Specialist, Tall Timbers Research Station, 13093 Henry Beadel Drive, Tallahassee, FL 32312, USA, areid@ttrs.org (Reid); and Professor, Natural Resource Ecology and Management Dept, Oklahoma State University, Stillwater, OK 74078, USA (Fublendorf). Research was funded by Oklahoma State University. At the time of the research, the senior author was a graduate research assistant, Natural Resource Ecology and Management Dept, Oklahoma State University, Stillwater, OK 74078, USA. 